\title{
Penerapan Teori Keadilan dalam Putusan Harta Bersama (Analisis Perkara Nomor 0346/Pdt.G/20 I 7/PA.Ktb)
}

\author{
Muhammad Nafi ${ }^{*}$ \\ Citra Mutiara Solehah ${ }^{2}$ \\ *'Universitas Terbuka UPBJJ Banjarmasin \\ ${ }^{2}$ Universitas Lambung Mangkurat Banjarmasin \\ nawafi82@gmail.com
}

\begin{abstract}
Justice in the decision of a case is the main objective of the trial process carried out. The theories of justice written by experts must have been understood by the judge. In the case of a joint property suit, it is necessary to apply the methods of justice by the judge in deciding the case. Although the regulations governing shared assets are divided into half each, in reality, there are proven legal facts in the trial to conduct contra legem. However, in the decision of the Kotabaru Religious Court Number 0346/Pdt.G/20 I 7/PA.Ktb, although it was evident that the joint property, which was one of the sources of income from the Plaintiff and Defendant in his life, was entirely controlled by the Defendant since the separation from the Plaintiff. The Plaintiff even had to pay more for his livelihood because he had to live and earn a living outside the joint property. The Panel of Judges decided that the joint property was divided in half each to the Plaintiff and Defendant. This has become a problem in the application of the theory of justice that takes into account the Plaintiff's contributions and losses in the joint venture. This study aims to describe how the legal considerations of the judges, and their relationship with the theory of justice used by the Panel of Judges.
\end{abstract}

Keywords: Theories of Justice, Contra Legem, Joint Property

\begin{abstract}
Abstrak
Keadilan dalam putusan sebuah perkara adalah menjadi tujuan utama dari proses persidangan yang dilakukan. Teori-teori keadilan yang ditulis oleh para ahli tentu telah difahami oleh hakim. Pada perkara gugatan harta bersama diperlukan penerapan teoriteori keadilan tersebut oleh hakim dalam memutus perkara. Meskipun regulasi mengatur harta bersama dibagi masing-masing separo, namun pada kenyataan ada fakta persidangan yang terbukti dipersidangan untuk melakukan contra legem. Namun demikian dalam putusan Pengadilan Agama Kotabaru Nomor 0346/Pdt.G/20I7/PA.Ktb, meskipun terbukti bahwa harta bersama yang menjadi salah satu sumber penghasilan dari Penggugat dan Tergugat dalam kehidupannya, dikuasai oleh Tergugat secara penuh sejak perpisahan dengan Penggugat. Bahkan Penggugat harus mengeluarkan biaya penghidupan yang lebih besar karena harus tinggal dan mencari penghasilan di luar harta bersama tersebut. Majelis Hakim memutuskan bahwa harta bersama tersebut dibagi masing-masing separo kepada Penggugat dan Tergugat. Hal tersebut menjadi problematika dalam penerapan teori keadilan yang memperhatikan kontribusi dan kerugian Penggugat dalam kongsi harta bersama tersebut. Penelitian ini bertujuan mendeskripsikan pertimbangan hukum majelis hakim dan hubungannya dengan teori keadilan yang digunakan oleh Majelis Hakim.
\end{abstract}

Kata Kunci: Teori Keadilan, Contra Legem, Harta Bersama

\section{PENDAHULUAN}

Gugatan tentang harta bersama muncul ketika terjadi permasalahan dalam perkawinan. Pada lazimnya sebelum pernikahan, jarang sekali pasangan suami istri memperjanjikan pemisahan harta bersama, karena mayoritas pernikahan didasari dari niat untuk memulai hidup bersama dari titik nol. Namun tidak sedikit juga yang memperjanjikan pemisahan harta bersama sebelum pernikahan, karena pertimbangan yang bersifat teoretis yuridis, maupun karena pertimbangan sosiologis ekonomis.

Penulis menemukan keluhan dari pihak yang berperkara bahwa mereka kecewa dengan putusan pembagian harta bersama yang diputuskan oleh Pengadilan. Alasan mereka beragam, setidaknya mereka menginginkan pembagian tersebut berdasarkan kontribusi mereka terhadap perolehan harta bersama. (Kurniawan, 2018, pp. Jilid 5, h. 160) menyebutkan bahwa bukti kontribusi dalam perolehan harta bersama harus dipertimbangkan oleh hakim untuk melakukan contra legem. Meskipun keadilan adalah hal yang abstrak, namun harus dirasakan oleh pencari keadilan. (Gunawan, 2019) menyarankan bahwa hakim yang menyelesaikan sengketa gugatan harta bersama tidak hanya memperhatikan aturan tertulis, namun sebaiknya memiliki nilai hukum yang ada di masyarakat, sehingga rasa adil dapat dirasakan oleh masyarakat. (Khosyi'ah, 2017) memberikan penilaian bahwa pembagian harta bersama di Indonesia telah diatur dalam Kompilasi Hukum Islam dalam pasal 96 dan 97 membuktikan bahwa hukum Islam fleksibel. Khosyi'ah beralasan bahwa pasal-pasal tersebut bersifat mengatur (regelen) bukan memaksa (dwigen), sehingga berimplikasi bahwa putusan hakim tidak mutlak dibagi sama rata antara suami istri, dan secara kasuistik kententuan dalam pasal tersebut dalam dikesampingkan.

Penulis menemukan putusan pada Pengadilan Agama Kotabaru dengan Nomor 
0346/Pdt.G/20I7/PA.Ktb, yang merupakan gugatan komulasi antara cerai gugat dan gugatan harta bersama. Dalam putusan tersebut telah terbukti dalam persidangan bahwa Tergugat menguasai harta bersama selama perpisahan sebelum proses perceraian di Pengadilan Agama Kotabaru, dan Penggugat harus menghidupi dirinya dan anaknya di luar dari hasil harta bersama tersebut, namun majelis hakim memutuskan bahwa harta bersama yang dibuktikan di persidangan dibagi $1 / 2$ untuk Penggugat dan $1 / 2$ untuk Tergugat. Memang dalam perkara ini keadilan pembagian tidak dibagi berdasarkan kontribusi Penggugat dan Tergugat dalam harta bersama, namun penguasaan harta bersama oleh Tergugat selama beberapa bulan semasa perpisahan mestinya dipertimbangkan oleh majelis hakim dalam memutus perkara ini.

Sehingga menarik untuk dikaji pertimbangan hukum majelis hakim Pengadilan Agama Kotabaru tersebut, untuk menjawab pertanyaan teori keadilan yang diterapkan oleh majelis hakim dalam putusan pembagian harta bersama dan bagaimana putusanputusan serupa diputuskan pada pengadilan lainnya.

\section{METODOLOGI PENELITIAN}

Penelitian ini adalah penelitian normatif dengan menggunakan pendekatan perundang-undangan (statue approach). Pendekatan ini bersfiat kualitatif, dikarenakan penulis menelaah regulasi yang berkaitan dengan harta bersama untuk menganalisa putusan Nomor 0346/Pdt.G/20I7/PA.Ktb. Metode penelitian yang penulis gunakan adalah metode penelitian deskriptif analitif.

\section{HASIL PENELITIAN DAN PEMBAHASAN}

Dalam Alquran dan hadits serta kitab-kitab fiqih, khususnya kitab fiqih perkawinan yang disusun oleh para ulama terdahulu, tidak ada yang membicarakan harta bersama dalam rumah tangga. Permasalahan mengenai harta bersama mulai muncul belakangan di sebagian dunia Islam selepas penjajahan barat. Sedangkan di sebagian dunia Islam lainnya hal ini tetap tidak dikenal dan tidak berlaku. (Susanto, 20II, p. 129).

Syarkhasi menyatakan di dalam kitab fikih ditemukan pembahasan tentang mata' al-bait (perabotan rumah tangga), yang dalam menjelaskan persoalan tersebut, fukaha menjelaskan bahwa apabila terjadi sengketa tentang kepemilikan perabotan tersebut, baik sengketa tersebut terjadi pada saat belum bercerai atau telah bercerai, maka ada ketentuan-ketentuan yang ditetapkan oleh para ulama mazhab. (Asy-Syarkhasi, 1993). Imam Hanafi, menyebutkan bahwa untuk memutuskan perabot siapa yang disengketakan tersebut, maka harus dilakukan proses persidangan dengan memperhatikan fungsi dari perabotan yang diperselisihkan tersebut, seperti perabotan yang biasa dipakai oleh laki-laki, atau perabotan yang biasa dipakai oleh perempuan atau digunakan bersama. Apabila yang diperebutkan adalah perabotan yang biasa digunakan oleh laki-laki, maka hakim harus meminta suami untuk bersumpah demikian sebaliknya, sedangkan apabila perabotan tersebut adalah dipakai bersama maka, dihukumkan menjadi milik laki-laki. Namun penulis tidak sependapat dengan pendapat Imam Abu Hanifah ini, dan lebih cenderung memilih pendapat Imamiyah yang berpendapat bahwa penggugat dan tergugat harus membuktikan perolehan harta perabotan tersebut. Apabila tidak bisa dipenuhi, maka harta tersebut dibagi dua.

Imam Syafii menetapkan bahwa suami istri yang terlibat sengketa perabotan harus diperintahkan untuk bersumpah, maka apabila salah satu tidak mau bersumpah, maka harta tersebut adalah milik pihak yang mau bersumpah. Jika kedua-duanya bersumpah maka harta tersebut dibagi dua, baik harta tersebut biasa dipakai oleh salah satu pihak, atau biasa dipakai bersama.(al-Shafii, 1403)

Harta bersama didefinisikan sebagai aset yang diperoleh oleh pasangan menikah selama pernikahan. Kemudian harta bersama dikategorikan sebagai syirkah muwafadah karena kemitraan suami-istri dalam aset bersama tidak terbatas, semua aset yang dihasilkan selama pernikahan menjadi milik bersama, termasuk warisan dan bantuan atau hadiah. Sementara harta bersama yang disebut sebagai syirkah abdan lebih besar dari suami saya dalam masyarakat Indonesia, keduanya bekerja untuk kehidupan keluarga.

Para penyusun Kompilasi Hukum Islam melakukan pencarian terhadap jalan syirkah abdan dengan hukum adat. Cara pendekatan ini tidak bertentangan dengan kebolehan menjadikan "urf sebagai sumber hukum dan sejiwa dengan kaidah 'al adatu al muhakkamah.(Ramulyo, 1996, p. 33)

Pendapat tersebut memang bisa dibenarkan bahwasanya sebuah kebiasaan atau 'urf bisa dijadikan sebagai dasar pengambilan hukum Islam. Jadi, dalam buku-buku figh tidak membahas harta bersama secara khusus, tetapi dalam Kompilasi Hukum Islam yang juga merupakan figh, Indonesia telah mengatur harta bersama, harus menjadi referensi pengadilan agama untuk memutuskan sengketa gugatan harta bersama bagi mereka yang beragama Islam.

Harta tersebut ada yang diperoleh sebelum perkawinan dan sesudah dilangsungkannya perkawinan. Mengenai harta kekayaan dalam perkawinan telah diatur dalam hukum positif Indonesia yaitu Undang-Undang Nomor I Tahun 1974 tentang Perkawinan, Kitab Undang-Undang Hukum Perdata dan Kompilasi Hukum Islam. Namun dalam tulisan ini hanya akan membahas pengaturan harta kekayaan dalam perkawinan sebagaimana diatur dalam Undang-Undang Nomor I Tahun 1974 dan Kompilasi Hukum Islam.

Namun ada potensi yang tercipta dari perkawinan yaitu perceraian. Perceraian bukan saja dikarenakan hukum agama dan perundang-undangan, tetapi juga berakibat sejauh mana pengaruh budaya malu dan kontrol dari masyarakat, pada masyarakat yang kekerabatannya sangat kuat, perceraian adalah kata sulit yang dikeluarkan tetapi pada masyarakat yang memiliki kelemahan sistem kekerabatannya maka akan mudah terjadi perceraian. 
Berbeda halnya dengan Undang-Undang Nomor I Tahun 1974 yang mengatur tentang harta bersama secara singkat hanya dalam tiga pasal, pasal 35 sampai pasal 37, dalam Kompilasi Hukum Islam masalah harta bersama diatur secara lebih lengkap mulai pasal 85 sampai pasal 97.

Ketentuan mengenai harta kekayaan dalam perkawinan yaitu Pasal 35 sampai dengan Pasal 37 Undang-Undang Nomor I Tahun 1974 tentang Perkawinan dan Pasal 85 sampai dengan Pasal 97 Kompilasi Hukum Islam, pada akhirnya menjelaskan tentang tanggung jawab masing-masing suami atau istri, baik antara mereka sendiri ataupun terhadap pihak ketiga. Dalam Pasal 89 dan 90 Kompilasi Hukum Islam djelaskan bahwa suami bertanggung jawab menjaga harta bersama, harta istri maupun hartanya sendiri. Istripun juga turut bertanggung jawab terhadap harta bersama ataupun harta suami yang ada padanya.

Perceraian akan membawa berbagai akibat hukum, salah satunya adalah berkaitan dengan harta bersama dalam perkawinan. Undang-Undang Nomor I Tahun 1974 tentang Perkawinan mengatur tentang harta bersama antara lain:

I. Pasal 35 ayat (I) menyatakan bahwa harta benda yang diperoleh sepanjang perkawinan menjadi harta bersama, dan Pasal 35 ayat (2) menyatakan bahwa harta bawaan dari masing-masing suami dan istri dan harta benda yang diperoleh masing-masing sebagai hadiah atau warisan adalah di bawah penguasaan masing-masing penerima, sepanjang para pihak tidak menentukan lain.

2. Pasal 36 ayat (I) yang menyatakan bahwa mengenai harta bersama suami dan istri dapat bertindak atas persetujuan kedua belah pihak, dan Pasal 36 ayat (2) yang menyatakan bahwa mengenai harta bawaan masing-masing, suami dan istri mempunyai hak sepenuhnya untuk melakukan perbuatan hukum mengenai harta bersama.

3. Pasal 37 ayat (I) yang menyatakan bahwa bilamana perkawinan putus karena perceraian maka harta bersama diatur menurut hukumnya masing-masing. Dalam penjelasan Pasal 37 ayat (I) ini ditegaskan hukum masing-masing ini ialah hukum agama, hukum adat dan hukum-hukum lainnya yang bersangkutan dengan pembagian harta bersama tersebut.

Harta bersama ada pada saat perkawinan berlangsung sedangkan harta bawaan diperoleh sebelum berlangsungnya perkawinan, namun kenyataannya dalam keluarga-keluarga di Indonesia banyak yang tidak mencatat tentang harta bersama yang dimilikinya. Pada perkawinan yang masih baru pemisahan harta bawaan dan harta bersama itu masih jelas pembagiannya, akan tetapi pada usia perkawinan yang sudah tua harta bawaan maupun harta bersama itu sudah sulit untuk dijelaskan secara terperinci satu persatu.

$\mathrm{Hal}$ ini diatur dalam Pasal 35 Undang-Undang Nomor I Tahun 1974 tentang Perkawinan, yaitu sebagai berikut:
I. Harta benda yang diperoleh selama perkawinan menjadi harta bersama

2. Harta bawaan dari masing-masing suami dan istri dan harta benda yang diperoleh masing-masing sebagai hadiah atau warisan, adalah di bawah penguasaan masing-masing sepanjang para pihak tidak menentukan lain.

Dari pengertian Pasal 35 di atas, dapat dijelaskan tentang aset bersama yang diperoleh dari aset yang diperoleh dalam ikatan pernikahan di luar warisan, hibah. Oleh karena itu, aset yang diperoleh oleh suami atau istri dari kontrak pernikahan dipegang bersama oleh suami dan istri. Aset yang diperoleh sebelum kontrak pernikahan, yaitu, aset asli atau warisan, aset tersebut adalah milik masing-masing suami istri.

Pembagian harta bersama akibat perceraian menurut KUH Perdata dijelaskan dalam Pasal $128 \mathrm{KUH}$ Perdata yang berbunyi:

"Setelah bubarnya persatuan, maka harta benda kesatuan dibagi dua antara suami dan isteri, atau antara para ahli waris mereka masing-masing, dengan tak mempedulikan soal dari pihak yang manakah barangbarang itu diperoleh".

Pembagian harta bersama menurut Pasal 128 KUH Perdata memberikan penegasan, bahwa harta bersama yang dihasilkan selama perkawinan dibagi sama rata antara suami dan isteri, jika diantara keduanya terjadi perceraian. Pembagian tersebut tidak dipengaruhi oleh proses didapatnya harta bersama, baik diperoleh oleh suami maupun isteri.

Proses pembagian harta bersama dalam $\mathrm{KUH}$ Perdata, tanpa melihat siapa yang mengusahakan perolehan harta bersama, didasarkan difinisi harta bersama dalam Pasal $119 \mathrm{KUH}$ Perdata yang menganut percampuran harta secara mutlak setelah terjadinya perkawinan, senyampang hal tersebut tidak didahului dengan perjanjian perkawinan diantara suami dan isteri.

Jenis-jenis harta yang menjadi objek harta bersama dalam KUH Perdata adalah:

I. Benda bergerak dan benda tidak bergerak, baik yang sudah ada pada saat perkawinan maupun yang diperoleh setelah perkawianan, serta harta yang didapatkan secara cuma-cuma dari harta waris dan hibah selama pihak yang memberi tidak menentukan lain;

2. Harta beban, yaitu hutang yang diperbuat suami dan isteri;

3. Harta aktiva dan pasiva sebelum maupun setelah perkawinan. (Pasal 120, I2I, dan I22 KUH Perdata) Tabel Perbedaan dan Persamaan Konsep Harta Bersama antara UU Nomor I Tahun 1974 tentang Perkawinan dan KUHPerdata

\begin{tabular}{|c|l|ll|}
\hline Regulasi & \multicolumn{1}{|c|}{ Persamaan } & Perbedaan \\
\hline KUHPerdata & $\begin{array}{l}\text { Mengakui } \\
\text { konsep harta } \\
\text { bersama } \\
\text { dengan adanya } \\
\text { perkawinan }\end{array}$ & $\begin{array}{l}\text { Tidak } \\
\text { mengakui } \\
\text { adanya harta } \\
\text { bawaan antara } \\
\text { suami dan }\end{array}$ \\
\hline
\end{tabular}




\begin{tabular}{|c|c|c|}
\hline & & $\begin{array}{l}\text { istri; } \\
\text { Harta yang } \\
\text { diperjanjikan } \\
\text { tidak menjadi } \\
\text { harta bersama; }\end{array}$ \\
\hline $\begin{array}{l}\text { UU Nomor I } \\
\text { Tahun } 1974\end{array}$ & I. & $\begin{array}{l}\text { Mengakui } \\
\text { harta bawaan } \\
\text { antara suami } \\
\text { dan istri } \\
\text { Hadiah, } \\
\text { warisan dan } \\
\text { harta yang } \\
\text { diperjanjikan } \\
\text { tidak menjadi } \\
\text { harta bersama; }\end{array}$ \\
\hline
\end{tabular}

Perceraian akan terjadi jika hakim telah membuat keputusan yang memiliki kekuatan hukum permanen. Hakim dan keputusan ibarat dua sisi mata uang yang tidak bisa dipisahkan. Kemampuan dan kualitas hakim untuk memutuskan kasus tercermin dalam keputusan mereka. Maka tidak mengherankan jika banyak pihak menyebut putusan itu sebagai mahkota hakim. Ada harapan besar bahwa para hakim akan dapat menghasilkan keputusan yang adil, argumentatif, dan rasional. Secara filosofis, keputusan hakim adalah keputusan yang memiliki pertimbangan yang sama dengan pertimbangan Tuhan. Hakim perlu melakukan interogasi filosofis apakah mandat yang dilakukan sebagai penegak hukum dan keadilan telah benar-benar dijaga dan dijalankan secara profesional, sehingga produk vonis mampu memberikan keadilan sesuai dengan hukum yang hidup dan berkembang di masyarakat. (Yusuf, 2014, p. 74)

Manurut Aristoteles konsep keadilan dapat digolongkan menjadi 3 bagian, pertama konsep keadilan distributif, yaitu keadilan yang memberikan kepada setiap orang jatah sesuai dengan jasanya. Kedua konsep keadilan komulatif, yaitu keadilan yang diberikan dengan cara memberikan atau memabagi sama kepada setiap orang tanpa mengingat jasa masing-masing. Konsep keadilan distributif menekankan pada unsur proporsional sedangkan konsep keadilan komulatif menekankan pada unsur persamaan. (Judiasih, 2015, p. 39)

Ketiga konsep keadilan korelatif, yaitu keadilan yang bertujuan untuk mengoreksi kejadian yang tidak adil, dalam hal ini keadilan dalam hubungan antara satu orang dengan orang lain berupa keseimbangan antara yang yang diberikan dengan yang diterima. Judiasih, 2015)

Keadilan menurut John Rawls adalah kebajikan utama dalam isntitusi sosial sebagaimana kebenaran dalam sistem pemikiran. Berkenaan dengan prinsip keadilan John Rawls telah melahirkan keadilan fairness, salah satu gagasan utama dari teori keadilan ini adalah memandang berbagai pihak dalam situasi awal sebagai rasional dan sama-sama netral. (Rawls, 201I, pp. 3,15). Lihat juga (Rawl, I97I).

Pola pembagian harta bersama dalam KUH Perdata yang membagi sama rata harta perkawinan, mengejawantakan teori keadilan komulatif yang di kemukakan oleh Aristoteles, dalam hal ini kesamaan hak yang didapatkan oleh setiap orang haruslah sama.

Melihat hal ini maka unsur keadilan komulatif memang terpenuhi pada Pasal $128 \mathrm{KUH}$ Perdata, keadilan komulatif tersebut memberikan pengertian memberikan hak kepada setiap orang jatah yang sama banyaknya tanpa mengingat jasa masing-masing pihak dalam mengusahakan atau mendapatkan harta selama perkawinan. (Judiasih, 20I5, p. 39)

Namun demikian konsep Pasal $128 \mathrm{KUH}$ Perdata tersebut dikoreksi dengan ketentuan Pasal I32 KUH Perdata yang menyatakan:

"Setiap isteri berhak melepaskan haknya atas persatuan; segala perjanjian bertentangan dengan ketentuan ini, adalah batal; sekali melepasnya, tak bolehlah ia menuntut barang suatu pun dari persatuan, melainkan barangbarang slimut-seprei-dan pakaian-pakaian pribadinya.

Karena pelepasan itu, terbebaslah ia dari kewajibannya akan ikut membayar utang-utang persatuan.”. pada masyarakat Madura jika suami dianggap sebagai pihak yang menyebabkan perceraian maka harta bersama yang diberikan tidak lebih besar dari bagian isteri, begitupun pada masyarakat Banjar yang jelas-jelas dalam prinsipnya menghendaki pembagian yang sesuai dengan proporsi pihak yang mencari. Sehingga dalam hal ini berlaku prinsip keadilan distributif.

Keadilan distributif menghendaki nilai sebuah keadilan akan lahir dengan memberikan proporsi sesuai dengan perbuatan atau jasa yang diperbuat oleh seorang yang menginginkan nilai keadilan tersebut ditegakkan dan direalisasikan. (Judiasih, 20I5, p. 39)

Perbandingan pembagian harta bersama akibat perceraian menurut KUH Perdata dan hukum adat mempunyai perbedaan dan persamaan pada masingmasing proses pembagian yang ada. Persamaan pembagian harta bersama akibat perceraian dalam KUH Perdata dan hukum adat adalah pada kedua sisi peraturan hukum menginginkan adanya keadilan bagi masing-masing pihak suami dan isteri.

Keadilan yang diingini oleh $\mathrm{KUH}$ Perdata lebih kepada keadilan yang memandang persamaan hak antara pihak suami dan isteri, dengan pemerataan pembagian jika terjadi perceraian. persamaan pembagian yang diinginkan tanpa melihat jasa atau usaha siapa yang menghasilkan harta yang dibagi tersebut, dalam hal inilah keadilan komulatif sebagai prinsip yang terkandung dalam Pasal $128 \mathrm{KUH}$ Perdata sebagai dasar aturan pembagian harta bersama akibat perceraian dalam $\mathrm{KUH}$ Perdata.

Pembagian harta gono-gini bagusnya dilakukan secara adil, sehingga tidak menimbulkan ketidakadilan antara mana yang merupakan hak suami dan mana hak isteri. Menurut Erna Wahyuningsih dan Putu Samawati menjelaskan bahwa cara mendapatkan harta bersama, sebagai berikut:

a. Pembagian harta bersama dapat diajukan bersamaan dengan saat mengajukan gugat cerai dengan menyebutkan harta bersama dan buktibukti bahwa harta tersebut diperoleh selama 
perkawinan dalam "posita" (alasan mengajukan gugatan). Permintaan pembagian harta disebutkan dalam petitum (gugatan). (Wahyuningsih \& Samawati, 2006, p. 127)

b. Pembagian harta bersama diajukan setelah adanya putusan perceraian, artinya mengajukan gugatan atas harta bersama. Bagi yang beragama Islam gugatan atas harta bersama diajukan ke pengadilan agama di wilayah tempat tinggal isteri. Untuk non-Islam gugatan pembagian harta bersama diajukan ke pengadilan negeri tempat tinggal termohon. (Nagara, 2016, p. 52)

Pembagian harta bersama dalam Pasal UndangUndang Nomor I Tahun 1974 Tentang Perkawinan dan Kompilasi Hukum Islam belum berbasis nilai keadilan, karena masih sering tidak mencerminkan rasa keadilan bagi para pihak pencari keadilan untuk memperoleh keadilan dalam pembagian harta bersama. Sesuai dengan ketentuan Pasal $97 \mathrm{KHI}$, "Janda atau duda cerai hidup masing-masing berhak seperdua dari harta bersama sepanjang tidak diitentukan lain dalam perjanjian perkawinan."

Majelis Hakim dalam menentukan pembagian harta bersama akibat perceraian lebih berpedoman kepada ljtihad (penemuan hukum). ljtihad yang dilakukan oleh Majelis Hakim adalah ljtihad Tathbiqiy, yaitu upaya menerapkan hukum secara tepat terhadap suatu kasus. Wujud ljtihad Tathbiqiy yang dilakukan oleh Majelis Hakim dalam menentukan pembagian harta bersama akibat perceraian tersebut adalah ketika Majelis Hakim menggunakan Teori Hukum dalam memeriksa kasus dengan mengutamakan nilai keadilan dan Kemaslahatan. Teori Keadilan yang dimaksudkan di sini adalah Keadilan Distributif dan keadilan Principle Difference.

Untuk mengetahui tentang praktik putusan Pengadilan Agama dalam perkara pembagian harta bersama, akan dikemukakan beberapa putusan tentang pembagian harta bersama. Pertama, putusan Pengadilan Agama Kotabaru Nomor Perkara 0346/Pdt.G/2017/PA.Ktb ini adalah perkara cerai gugat, dimana yang mengajukan permohonan cerai adalah istri sebagai Penggugat, yang dalam petitumnya Penggugat meminta majelis hakim untuk menceraikan Penggugat dengan suaminya (Tergugat) dan juga menyatakan bahwa harta yang dikumpulkan oleh Penggugat dan Tergugat pada masa perkawinan mereka adalah sah harta bersama dan dibagi kepada Penggugat dan Tergugat;

Dalam analisa penulis, bahwa mengkomulasikan gugatan cerai dengan gugatan harta bersama memiliki kelebihan dan kekurangan (resiko). Kelebihannya adalah biaya yang dikeluarkan untuk dua perkara tersebut menjadi lebih ringan. Resikonya adalah apabila perceraian tidak dikabulkan, maka harta bersama juga tidak bisa diperiksa. Demikian lagi apabila gugatan cerai diterima dan gugatan harta bersama akan diperiksa, maka perceraian akan berlarut-larut. Karena bisa saja, pihak yang tidak terima dengan putusan pembagian harta bersama, akan mengajukan upaya hukum selanjutnya, yang tentu memakan waktu tidak sebentar.
Majelis Hakim juga mempertimbangkan bahwa oleh karena telah terbukti bahwa harta sebagaimana dalam posita gugatan Penggugat point 3 dan petitum point 3 sebagai harta bersama antara Penggugat dengan Tergugat dan ternyata antara Penggugat dengan para Tergugat sampai saat ini belum membagi harta bersama tersebut, dan ternyata pula Penggugat dan Tergugat beragama Islam, maka berdasarkan ketentuan Pasal 37 Undang-Undang Nomor I Tahun 1974, yang menegaskan bahwa apabila perkawinan putus karena perceraian, harta bersama diatur menurut hukum masing-masing dan dalam Pasal 97 Kompilasi Hukum Islam di Indonesia, ditegaskan bahwa janda atau duda cerai hidup masing-masing berhak seperdua dari harta bersama, dan hal ini sesuai pula firman Allah dalam surat An-nisa ayat 32 berbunyi:

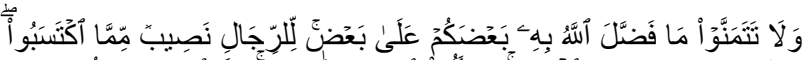

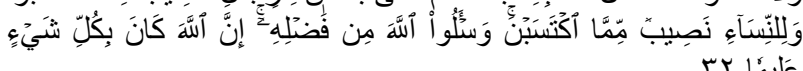

Artinya: "Dan janganlah kamu iri hati terhadap apa yang dikaruniakan Allah kepada sebahagian kamu lebih banyak dari sebahagian yang lain. (Karena) bagi orang laki-laki ada bahagian dari apa yang mereka usahakan, dan bagi para wanita (pun) ada bahagian dari apa yang mereka usahakan, dan mohonlah kepada Allah sebagian dari karunia-Nya. Sesungguhnya Allah Maha Mengetahui segala sesuatu";

Karenanya, I/2 (separo) dari harta bersama tersebut adalah bagian atau hak Penggugat dan 1/2 (separo) lainnya adalah bagian atau hak Tergugat;

Majelis Hakim mempertimbangkan juga bahwa oleh karena masing-masing Penggugat dan Tergugat berhak $1 / 2$ (separo) dari harta bersama tersebut, sedangkan ternyata harta tersebut dalam penguasaan Tergugat, maka Pengadilan patut menghukum kepada Penggugat dan Tergugat untuk membagi dua harta bersama tersebut secara natura, dan jika tidak dapat dibagi secara natura, maka dibagi secara in natura dengan dijual lelang dimuka umum dan hasilnya dibagi dua kepada Penggugat dan Tergugat;

Selanjutnya pada persoalan pembagian harta bersama, terbukti di persidangan:

I. bahwa sejak berpisah tempat tinggal setidaknya selama 3 (tiga) bulan terakhir, sampai saat ini Penggugat dan Tergugat tidak pernah hidup rukun lagi selayaknya pasangan suami istri. Penggugat dan Tergugat ternyata juga tidak pernah berhasil mencari solusi damai bagi keutuhan rumah tangga.

2. bahwa harta sebagaimana dalam posita gugatan Penggugat point 3 dan petitum point 3 sebagai harta bersama antara Penggugat dengan Tergugat dan ternyata antara Penggugat dengan para Tergugat sampai saat ini belum membagi harta bersama tersebut, dan ternyata pula Penggugat dan Tergugat beragama Islam;

3. Selama perpisahan sebelum perceraian, harta bersama tersebut dikuasai oleh Tergugat;

Dalam memutuskan porsi bagian harta bersama,

Majelis Hakim mempertimbangkan bahwa ada harta 
bersama Penggugat dan Tergugat yang memang belum dibagi. Sehingga Majelis Hakim merujuk pada Pasal 37 Undang-Undang Nomor I Tahun 1974, yang menegaskan bahwa apabila perkawinan putus karena perceraian, harta bersama diatur menurut hukum masing-masing dan dalam Pasal 97 Kompilasi Hukum Islam di Indonesia, ditegaskan bahwa janda atau duda cerai hidup masing-masing berhak seperdua dari harta bersama.

Hakim memutus perkara tersebut pada dasarnya tidak terikat pada teori-teori yang dikembangkan oleh para filsuf atau para ahli. Keadilan disini didasari oleh pasal 229 Kompilasi Hukum Islam yang berbunyi "Hakim dalam menyelesaikan perkaraperkara yang diajukan kepadanya, wajib memperhatikan dengan sungguh-sungguh nilai-nilai hukum yang hidup dalam masyarakat, sehingga putusnya sesuai dengan rasa keadilan". Majlis hakim melihat berdasarkan fakta dan bukti-butki di pengadilan, sehingga dalam mempertimbangkan rasa keadilan untuk memutus perkara tersebut hakim dapat melakukan kontra legem atau ijtihad sendiri.

Penulis menganalisa, bahwa Majelis Hakim mengesampingkan keadilan distributif yang mestinya didapatkan oleh Penggugat. Dari fakta persidangan Tergugat menguasai harta bersama tersebut, sehingga Penggugat dan anaknya yang masih kecil hidup diluar harta bersama, dan memerlukan biaya hidup tambahan ketika mesti harus hidup di luar harta bersama yang selain merupakan bangunan tempat tinggal, dan sumber penghasilan harian.

Menurut Charles Taylor keadilan mempunyai pengertian yang berbeda-beda, dalam hal ini pabila terjadi putusnya perkawinan, baik karena cerai atas gugatan pihak laki-laki maupun pihak perempuan, maka harta itu harus dibagi bersama. Namun hal ini Majlis hakim berpendapat bahwa putusan tersebut merupakan sebuah keadilan. Putusan dapat dilaksanakan ketika putusan hakim sudah mempunyai kepastian hukum. Lain halnya dengan putusnya hubungan karena kematian, hal itu sudah memiliki keputusan yang kuat. (Ramulyo, 1996, p. 34)

Sebelumnya dalam penelitian Khosyiah (2017) ditemukan bahwa Putusan Pengadilan Tinggi Agama Bandung dengan Putusan Nomor 248/Pdt.G/2010/PTA Bdg, telah membatalkan Putusaan Pengadilan Agama Cimahi dengan Nomor Putusan, 96/Pdt.G/2010/PA Cmhi yang memberikan harta bersama setengah (I/2) masing-masing antara janda dengan duda. Putusan PTA tersebut memberikan harta bersama $I / 3$ untuk duda dan 2/3 untuk janda. dengan beberapa pertimbangan kemaslahatan yang digali dari sebab-sebab dan alasan hukum dalam perkara banding yang diajukan.

$$
\text { Putusan Mahkamah Agung Nomor }
$$

226K/AG/2010 yang telah mengukuhkan putusan Pengadilan Agama Bantul dengan Nomor 229/Pdt.G/2009/PA Btl., yang memberikan bagian harta bersama $3 / 4$ bagi Termohon Kasasi yang dulu sebagai penggugat/terbanding, dan bagian I/4 bagi pemohon kasasi yang dulu sebagai tergugat dan pembanding.
Pada tingkat banding harta bersama dibagi dua. Akan tetapi putusan PengadilanTinggi Yogyakarta Agama Nomor 34/Pdt.G/2009/PTA Ygk. Tertanggal 18 November 2009 telah dibatalkan oleh Mahkamah Agung dengan nomor di atas. Dengan pertimbangan telah melakukan KDRT yang berdampak pada kekerasan fisik dan psikis bagi termohon kasasi.

Kamarusdiana dan Daniel Alfaruqi menyebutkan bahwa ada juga putusan Pengadilan Agama Mataram, yaitu putusan Nomor 195/Pdt.20I3/PA.Mtr. Perkara tersebut telah sampai pada tingkat banding pada Pengadilan Tinggi Agama Mataram dengan putusan Nomor 04/Pdt.G/20I4/PTA.Mtr, dan bahkan sudah selesai pada tingkat kasasi di Mahkamah Agung Republik Indonesia dengan putusan Nomor $629 \mathrm{~K} / \mathrm{Ag} / 2014$ dan telah dijadikan sebagai salah satu yurisprudensi dalam bidang hukum keluarga khususnya perkara harta bersama. Pada pokoknya majelis hakim tetap membagi harta bersama dengan porsi masing-masing pihak Penggugat dan Tergugat mendapatkan separo dari harta bersama.(Kamarusdiana \& AlFaruqi, 20l6)

Putusan PTA dan MA tersebut bisa dijadikan hukum asal atas alasan dan pertimbangan hukum lain yang sama 'illat hukumnya sebagai bentuk analogi (kias). $\mathrm{Hal}$ tersebut bisa dibenarkan sepanjang 'illat hukum mengarahkan adanya kesamaan. 'Illat hukum tersebut misalnya:

a. Kekerasan rumah tangga, pemabok, pemadat, zina (perselingkuhan), semuanya sama-sama merupakan tindak pidana kejahatan yang merusak moral agama dan kesusilaan.

b. Sama-sama merusak hubungan silaturrahmi.

c. Sama-sama berdampak pada terganggunya psykologis pasangannya.

d. Sama-sama tidak memelihara dan menjaga agama (hifzh al-diin) menjaga kehormatan (hifzh al-'irdh)

Ketentuan bagi rata (50\%:50\%) harta bersama dalam Pasal $97 \mathrm{KHI}$ untuk masing-masing suami-isteri belum tentu memenuhi rasa keadilan. Karena itulah untuk dapat memenuhi rasa keadilan bagi para pihak, tentunya harus mengedepankan aspek kemanfaatan dan keadilan, di samping aspek kepastian hukum dan keseimbangan, apakah yang bersangkutan memiliki komitmen menjaga keharmonisan keluarga dalam mewujudkan tujuan perkawinan yang sakinah, mawaddah, dan rahmah? Apakah juga yang bersangkutan memiliki komitmen untuk menjaga keutuhan dan keberkahan harta kekayaan yang menjadi harta bersama dalam perkawinan? Karena itu, dalam beberapa kasus yang nyata-nyata tidak memenuhi komitmen seperti itu, sejatinya pembagian harta bersama memperhatikan keadilan distributif, yang berbasis keseimbangan proporsional. Dengan demikian para hakim berpeluang besar melakukan diskresi dalam memutuskan perkara sesuai dengan 'illat hukum dan latar belakang yang menyertainya. Dalam keadaan demikian, perubahan 
putusan hukum yang progresif, termasuk dalam memutuskan perkara "harta bersama" tidak dapat terhindarkan.

Contra Legem, adalah hal yang dibolehkan sebagai dasarnya adalah UU Nomor 4 tahun 2004 pasal 28 (I) yaitu bahwa hakim wajib menggali, mengikuti dan memahami nilai-nilai hukum dan rasa keadilan yang hidup dalam masyarakat. Sedang pasal 2 ayat (I) UndangUndang Nomor 48 Tahun 2009 tentang Kekuasaan Kehakiman yang menyatakan bahwa peradilan dilakukan demi keadilan berdasarkan Ketuhanan Yang Maha Esa. Demikian juga pada pasal $229 \mathrm{KHI}$ mengemukakan bahwa hakim dalam menyelesaikan perkara-perkara yang diajukan kepadanya, wajib memperhatikan sungguhsungguh nilai-nilai hukum yang hidup dalam masyarakat sehingga putusannya sesuai dengan rasa keadilan.

Hakim memahami konsep dasar harta bersama tidak bisa dilepaskan dari bentuk kerjasama dalam membangun dan mempertahankan rumah tangga, makapembagian harta bersama tersebut harus dibagi secara proporsional, seimbangdengan pelaksanaan tugas dan tanggung jawabnya dalam rumah tangga serta besarnya peran masing-masing dalam menghasilkan harta bersama. Di sini makna keadilan distributif tidak selalu dengan pembagian yang sama rata, tetapi justru keadilan dapat terwujud dengan mempertimbangkan komitmen dan keseriusan dalam membangun rumah tangga yang harmoni, disamping besaran kontribusi antara usaha dengan hasil, dan kewajiban dengan hak yang dilakukan kedua belah pihak.

Sehingga menurut penulis, Majelis Hakim memutuskan perkara ini dengan menganut keadilan yang komutatif yaitu memberikan kepada setiap orang bagian yang sama. Maksudnya memberikan kepada setiap orang apa yang menjadi haknya berdasarkan kapada azas kesamaan. Dalam putusan ini tidak ada yang salah dalam teori hukum acaranya, namun penulis lebih cenderung berpikir bahwa dalam kasus perceraian sebagaimana terbukti dalam persidangan ini Tergugat dengan menguasai harta bersama selama beberapa bulan, sedangkan Penggugat dan anak-anaknya tinggal di tempat yang mengharuskan mereka mengeluarkan uang lagi, sehingga semestinya teori keadilan distributif dapat diterapkan dalam putusan ini.

\section{SIMPULAN}

Perkawinan yang berakhir dengan perceraian seringkali diiringi dengan sengketa harta bersama. Hal tersebut dapat diduga karena keadaan emosi para pihak yang merasa tidak puas dengan keadaan masing-masing pihak. Meskipun tidak sedikit pula yang dalam akhir perkawinan, mereka mengakhirinya dengan baik-baik dan sepakat memberikan harta bersama kepada anakanak mereka. Tidak sedikit pula yang harus berakhir di ujung palu hakim, karena tidak dapat diselesaikan secara kekeluargaan.

Perceraian sering kali diawali dengan perpisahan tempat tinggal, dan tentu salah satu pihak pergi meninggalkan harta bersama yang mereka kumpulkan pada masa perkawinan. Apalagi harta bersama tersebut adalah modal dalam penghidupan sehari-hari mereka. Perkara Gugatan Cerai yang dikumulasikan dengan Gugatan Harta Bersama Nomor 00346/Pdt.G/20I7/PA.Ktb, diputuskan oleh majelis hakim untuk membagi harta bersama tersebut masingmasing mendapatkan separo. Meskipun dalam fakta persidangan telah terbukti bahwa Tergugat menguasai harta bersama yang salah satunya menjadi sumber penghidupan Penggugat dan Tergugat. Sebenarnya selain majelis hakim dapat menempuh contra legem dengan memperhatikan dan mempertimbangkan kehidupan Penggugat selama berpisah dengan Tergugat. Keadilan distributive yang mempertimbangkan sisi-sisi kemanusiaan dan kontribusi serta kearifan lokal mesti dilakukan oleh penegak hukum yang juga penegak keadilan.

Penelitian selanjutnya yang dapat dilakukan oleh peneliti yang tertarik membahas tentang harta bersama adalah tentang putusan harta bersama di Pengadilan Negeri dikomparasikan dengan putusan harta bersama di Pengadilan Agama yang diajukan oleh pihak beragama Islam di wilayah tertentu. Sehingga dapat ditemukan dua hal, ada faktor apa yang menyebabkan muslim mengajukan perkara gugatan harta bersama di Pengadilan Negeri, dan apakah ada perbedaan pertimbangan hukum antara Pengadilan Negeri dan Pengadilan Agama, penelitian ini dapat bersifat kuantitatif dan kualitatif, yaitu menggabungkan analisa putusan dan wawancara atau angket untuk menemukan korelasi antara muslim mengajukan gugatan harta bersama ke Pengadilan Negeri dengan hasil yang diinginkan.

\section{DAFTAR PUSTAKA}

al-Shafii, M. b. I. (I403). al-Umm. Beirut: Dar al-Fikr. Asy-Syarkhasi, M. b. A. b. A. S. A.-S. (1993). Kitab AlMabsuth. Beirut: Dar al-Marifah.

Gunawan, A. (2019). Mencari Keadilan Sengketa Harta Gono-Gini (Telaah Perspektif Hukum Islam dan Hukum Positif). Jurnal Yustitia, Volume I8(I), 8.

Judiasih, S. D. (20I5). Kajian Terhadap Kesetaraan Hak dan Kedudukan Suami dan Istri atas Kepemilikan Harta Dalam Perkawinan (D. Sumayyah Ed.). Bandung: PT Refika Aditama.

Kamarusdiana, \& AlFaruqi, D. (20I6). Konsep Hukum Penyelesaian Sengketa Harta Bersama di Indonesia (Analisis Perkara No. 195/Pdt. 2013/PA. Mtr, Putusan No. 04/Pdt. G/20I4/PTA. Mtr, dan Putusan No. 629 $\mathrm{K} / \mathrm{Ag} / 20 \mathrm{I}$ 4). Jurnal Indo-Islamika, 6(2), 263-292.

Khosyi'ah, S. (2017). Keadilan Distributif Atas Pembagian Harta Bersama Dalam Perkawinan Bagi Keluarga Muslim di Indonesia. Al-Manahij: Jurnal Kajian Hukum Islam, XI(I), I4.

Kurniawan, M. B. (20/8). Pembagian Harta Bersama Ditinjau Dari Besaran Kontribusi Suami Istri Dalam Perkawinan (Kajian Putusan Nomor 6I8/PDT.G/20I2/PA.BKT). AHKAM: Jurnal IImu 
Muhammad Nafi dan Citra Mutiara Solehah.2020. Penerapan Teori Keadilan dalam Putusan Harta Bersama (Analisis Perkara Nomor 0346/Pdt.G/20I7/PA.Ktb)
Syariah,
17
$(351)$,
22.

doi:http://dx.doi.org/10.29123/jy.vl lil.224

Nagara, B. (20I6). Pembagian Harta Gono Gini atau Harta Bersama Setelah Perceraian Menurut Undang-Undang Nomor I Tahun 1974. Lex Crimen, $I(7), 7$.

Ramulyo, M. I. (1996). Hukum Perkawinan Islam. Jakarta: Bumi Aksara.

Rawl, J. (197I). A Theory of Justice. Massachussets: The Bellnap Press of Havard University Press.

Rawls, J. (20I I). Teori Keadilan: Dasar-dasar Filsafat Politik untuk Mewujudkan Keadilan Sosial dalam Negara. Yogyakarta: Pustaka Pelajar.

Susanto, D. (20II). Kupas Tuntas Masalah Harta GonoGini. Yogyakarta: Pustaka Yustisia.

Wahyuningsih, E., \& Samawati, P. (2006). Hukum Perkawinan Indonesia. Palembang: PT Rambang.

Yusuf, R. (20/4). Pembagian Harta Bersama akibat Perceraian Berbasis Nilai Keadilan. Jurnal Pembaharuan Hukum, Volume I(I), 10. 